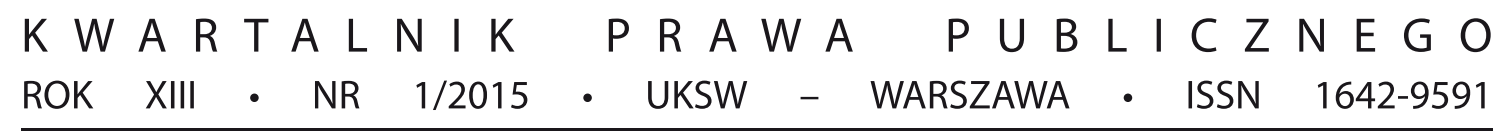

Radosław Mędrzycki*

\title{
MŁODZIEŻOWE ORGANY KONSULTACYJNE SAMORZĄDU TERYTORIALNEGO
}

\section{Podstawy prawne}

Od ponad czternastu lat na gminach spoczywa obowiązek realizacji zadania własnego o charakterze obligatoryjnym ${ }^{1}$ polegającego na podejmowaniu działań na rzecz wspierania i upowszechniania idei samorządowej wśród swoich mieszkańców, w tym zwłaszcza wśród młodzieży ${ }^{2}$. Wybór formy, w jakiej nastąpi realizacja tego zadania, został pozostawiony względnej swobodzie władz gminnych ${ }^{3}$ nie ulega jednak wątpliwości, iż muszą one podejmować jakieś działania realizujące ustawowy obowiązek.

* Mgr Radosław Mędrzycki - Asystent, Katedra Prawa Administracyjnego i Samorządu Terytorialnego, Wydział Prawa i Administracji, Uniwersytet Kardynała Stefana Wyszyńskiego w Warszawie.

1 Z. Niewiadomski [w:] Ustawa o samorzadzie gminnym. Komentarz z odniesieniem do ustaw o samorzqqdzie powiatowym i samorzq̨dzie województwa, red. R. Hauser, Z. Niewiadomski, Warszawa 2011, s. 70. Przepis art. 5 b został dodany na mocy art. 1 pkt 7 ustawy z 11.04 .2001 r. o zmianie ustaw: o samorządzie gminnym, o samorządzie powiatowym, o samorządzie województwa, o administracji rządowej w województwie oraz o zmianie niektórych innych ustaw (Dz. U. Nr 45, poz. 497 ze zm.).

2 Zgodnie z art. 5b ust. 1 ustawy z 8.3.1990 r. o samorządzie gminnym, t.j.: Dz. U. z 2013 r., poz. 594 ze zm. (dalej jako: u.s.g.): Gmina podejmuje działania na rzecz wspierania i upowszechniania idei samorządowej wśród mieszkańców gminy, w tym zwłaszcza wśród młodzieży.

3 A. Szewc [w:] Ustawa o samorzqdzie gminnym. Komentarz, A. Szewc, G. Jyż, Z. Pławecki, Warszawa 2012, s. 115. 
Władze gminy w zakresie realizacji wskazanego zadania, korzystając z gwarantowanej konstytucyjnie i ustawowo samodzielności, mogą decydować o podjęciu zróżnicowanych działań niewładczych ${ }^{4}$ albo też skorzystać z „nowej kompetencji” i utworzyć młodzieżową radę gminy ${ }^{5}$. Zgodnie z treścią art. 5 b ust. 2 u.s.g.: „Rada gminy na wniosek zainteresowanych środowisk może wyrazić zgodę na utworzenie młodzieżowej rady gminy mającej charakter konsultacyjny”. Jego dopełnieniem jest art. 5b ust. 3 u.s.g., w którym wskazano, iż „rada gminy, powołując młodzieżową radę gminy, nadaje jej statut określający tryb wyboru jej członków i zasady działania”.

Powołaniu młodzieżowej rady gminy mogą dodatkowo towarzyszyć działania niewładcze (np. organizacja pikniku, spotkań z mieszkańcami itp.) służące wspieraniu i upowszechnianiu idei samorządowej. Gmina może również zlecić organizacjom pozarządowym realizację działań niewładczych w ramach wskazanego zadania ${ }^{6}$.

Pozostałe ustawy ustrojowe dotyczące samorządu terytorialnego ${ }^{7}$ nie nakładają podobnego zadania na powiat i województwo samorządowe. W tym kontekście można zauważyć zróżnicowane podejście wśród władz samorządowych do legalności tworzenia młodzieżowych rad na innych stopniach samorządu terytorialnego. Zagadnienie istnienia młodzieżowych rad powiatu oraz młodzieżowych sejmików województwa można bowiem rozpatrywać z punktu widzenia braku podstawy prawnej do tworzenia takich organów - w doktrynie można spotkać twierdzenie, iż tworzenie młodzieżowych rad powiatu jest pozbawione podstawy prawnej ${ }^{8}$ jak również z perspektywy zadań, jakie przypisuje się powiatowi i województwu w systemie samorządu terytorialnego.

Jak zauważa B. Dolnicki istnienie młodzieżowych rad powiatu wywodzi się $\mathrm{z}$ art. 4 u.s.p. ${ }^{9} \mathrm{~W}$ niektórych powiatach w drodze uchwał powołano młodzieżowe rady powiatu ${ }^{10} \mathrm{w}$ oparciu o art. 4 ust. 1 pkt 1 u.s.p. (zadanie publiczne w zakresie

$4 \quad$ Z. Niewiadomski [w:] Ustawa o samorzqdzie gminnym..., s. 71.

$5 \quad$ Krzewienie idei samorządowej nie uprawnia natomiast do tworzenia funkcji społecznego asystenta (współpracownika) radnego - zob.: wyrok WSA w Gliwicach z 30.6.2011 r., sygn. akt IV SA/Gl 492/11; wyrok WSA w Gdańsku z 23.2.2012 r., sygn. akt III SA/Gd 536/11.

$6 \quad$ Zob. art. 4 ust. 1 pkt 13 ustawy z 24.4.2003 r. o działalności pożytku publicznego i o wolontariacie, t.j.: Dz. U. z 2014 r., poz. 1118 ze zm.

$7 \quad$ Ustawa z 5.6.1998 r. o samorządzie powiatowym, t.j.: Dz. U. z 2013 r. poz. 595 ze zm. (dalej jako: u.s.p.) oraz ustawa z dnia 5.6.1998 r. o samorządzie wojewódzkim, t.j. Dz. U. z 2013 r., poz. 596 ze zm.

$8 \quad$ T. Augustyniak-Górna, Zasady finansowania działalności młodzieżowych rad gmin, „Zeszyty Prawnicze Biura Analiz Sejmowych” 2008, nr 2, s. 240.

$9 \quad$ B. Dolnicki, Młodzieżowe rady miasta (powiatu, dzielnicy) [w:] Partycypacja społeczna w samorzq̨dzie terytorialnym, red. B. Dolnicki, Lex/el. 2014.

10 Zob. np.: Młodzieżowa Rada Powiatu Starogardzkiego (http://mrps.oppstarogard.pl); Młodzieżowa Rada Powiatu Wielickiego (http://mrpw.powiatwielicki.pl). 
edukacji publicznej) ${ }^{11}$ niemniej spotkać można również formę stowarzyszenia ${ }^{12}$. Jak pokazuje przykład Powiatu Lidzbarskiego możliwość powołania młodzieżowej rady powiatu przewidziano również w statucie powiatu ${ }^{13}$. W niektórych województwach powołano również młodzieżowe sejmiki wojewódzkie ${ }^{14}$, pomimo iż bez wątpienia brak jest wyraźnej podstawy ich tworzenia również w ustawie o samorządzie województwa.

Osadzenie promocji idei samorządowej na gruncie przepisów gminnych przez powoływanie młodzieżowych rad gmin wynika z różnicy ustrojowej jaka istnieje między gminą a powiatem i województwem. Ponadgminne stopnie samorządu terytorialnego pełnią funkcję uzupełniającą względem gminy. Na gminy jako podstawowe jednostki samorządu terytorialnego ustawodawca celowo nałożył obowiązek podejmowania działań na rzecz wspierania i upowszechniania idei samorządowej ${ }^{15}$. W tym kontekście traktowanie młodzieżowej rady gminy wyłącznie jako szkoły przygotowującej do przyszłego objęcia funkcji radnych konkretnej gminy byłoby zaprzeczeniem celów omawianej regulacji.

$\mathrm{Na}$ marginesie należy stwierdzić, iż prób utworzenia młodzieżowych rad powiatowych, w przeciwieństwie do wojewódzkich rad młodzieżowych, nie podjęto jednak w rządowym projekcie ustawy o przedstawicielstwach młodzieży i ich uczestnictwie w życiu publicznym, który został wniesiony do Sejmu w 2005 r. ${ }^{16}$ Należy zatem odczytywać, iż utrzymującą się od wielu lat intencją ustawodawcy jest istnienie na gruncie lokalnym i ponadlokalnym wyłącznie młodzieżowych rad gminnych.

Obok dość lakonicznych przepisów ustawowych należy wskazać na istnienie Standardów funkcjonowania w Polsce młodzieżowych rad gmin, młodzieżowych rad powiatu, uchwalonych w 2003 r. przez Federację Młodzieżowych Samorządów Lokalnych ${ }^{17}$. Federacja ta jest stowarzyszeniem grupującym gminy i powiaty, w których istnieją młodzieżowe samorządy lokalne. Standardy przez nią tworzone nie stanowią obowiązującego prawa, natomiast mogą być traktowane jako „istotne wskazówki co do funkcjonowania młodzieżowych rad"18. W tym miejscu należy wskazać, iż z samego tytułu dokumentu wynika opowiedzenie się przez Federację

\footnotetext{
11 Młodzieżowa Rada Powiatu Chojnickiego (http://powiat.chojnice.pl/ strona?id_ln=92\&id_typ=6\&id_kat=59).

12 Młodzieżowa Rada Powiatu Wielickiego (http://mrpw.powiatwielicki.pl/?page_id=333).

$13 \S$ 3a uchwały Nr OR.0007.175.2012 Rady Powiatu Lidzbarskiego z 20.12.2012 r. w sprawie ogłoszenia tekstu jednolitego uchwały w sprawie Statutu Powiatu Lidzbarskiego, tj.: Dz.Urz. Woj. Warmińsko-Mazurskiego z 2012 r., poz. 552.

14 Młodzieżowy Sejmik Województwa Dolnośląskiego (http://www.mlodziezowysejmik.pl).

15 Z. Niewiadomski [w:] Ustawa o samorządzie gminnym..., s. 70.

16 Druk sejmowy nr 3795/IV kad. Zob. również J. Lang, Uwagi do rzq̨dowego projektu ustawy o przedstawicielstwach młodzieży $i$ ich uczestnictwie $w$ życiu publicznym, „Zeszyty Prawnicze Biura Studiów i Ekspertyz Kancelarii Sejmu” 2005, nr 2, s. 59-62.

17 Dostępne na stronie www.mlodziez.wzp.pl.

18 B. Dolnicki, Młodzieżowe rady..., Lex/el 2014.
} 
za możliwością tworzenia młodzieżowych rad powiatowych. Nawiązania do tego dokumentu znajdują się w dalszej części artykułu.

\section{Charakter i cele działalności młodzieżowych organów konsultacyjnych}

$\mathrm{Z}$ art. $5 \mathrm{~b}$ ust. 2 in fine wynika, iż młodzieżowa rada gminy ma charakter konsultacyjny ${ }^{19}$. Zdaniem Ewy Olejniczak Szałowskiej jest to pomocniczy organ o charakterze doradczym ${ }^{20}$. Brak odpowiedniej regulacji dotyczącej młodzieżowych rad powiatów i sejmików województw nie pozwala w stosunku do nich dokonać tak samo kategorycznego stwierdzenia, zwłaszcza iż w wielu przypadkach konsultowanie nie stanowi pierwszoplanowej działalności opisywanych podmiotów ${ }^{21}$. Biorąc jednak pod uwagę ustawowo podstawowy charakter młodzieżowych rad gmin należy zadać pytanie o zakres i skutki konsultacji.

W zakresie konsultacyjnym można przyjąć dwa różniące się znaczenie od siebie stanowiska. Zgodnie z pierwszym z nich władze gminne mogą konsultować $z$ młodzieżową radą gminy wszystkie sprawy pozostające w ich kompetencjach przy czym wybór tych spraw należy do władz gminnych. Drugie z nich zakłada istnienie katalogu spraw, które z racji wieku i rozwoju mogą dotyczyć młodzieży. Do spraw związanych z młodym pokoleniem zaliczyć można edukację publiczną, kulturę, sport, imprezy w tym propagujące ideę samorządową ${ }^{22}$ byle katalog ten nie wykraczał poza zakres działania gminy ${ }^{23}$.

Rada gminy, a tym bardziej władze pozostałych szczebli samorządu, nie są związane stanowiskiem zajętym przez młodzieżowe organy konsultacyjne; konsultacje nie mają charakteru wiążącego.

Obok konsultacyjnej funkcji rad młodzieżowych wyróżnia się również inne ich cele. Ewelina Gierach w młodzieżowych radach widzi organy, których zadaniami są wdrożenie młodzieży w mechanizmy działania struktur samorządowych, integracja i współpraca środowisk młodzieżowych jak również działalność na rzecz ochrony praw ucznia ${ }^{24}$. Andrzej Szewc z kolei dostrzega, iż „nadrzędną ideą działania młodzieżowych rad gminy powinno być przygotowanie ich członków do

19 Charakter taki nadano młodzieżowej radzie po poprawce senackiej, która wpisywała się w zastrzeżenia wyrażone w opinii Biura Analiz Legislacyjnych Sejmu co do konstytucyjności młodzieżowej rady gminy, zob.: Biuletyn Komisji Sejmowych nr 4003/III kad.

20 E. Olejniczak-Szałowska [w:] Encyklopedia samorządu terytorialnego, cz. 1 - ustrój, red. M. Stahl, B. Jaworska-Dębska, Warszawa 2010, s. 111.

21 B. Dolnicki, Młodzieżowe rady..., LEX/el.

22 T. Moll, Młodzieżowe rady gminy, „Wspólnota” 2005, nr 15, s. 39.

23 Ibidem.

24 E. Gierach, Status prawny młodzieżowej rady gminy, „Zeszyty Prawnicze Biura Analiz Sejmowych" 2008, nr 2s. 236. 
przyszłej działalności społecznej w samorządzie terytorialnym”25. Bogdan Dolnicki stwierdza, że „podstawowe zadania rad mieszczą się w trzech płaszczyznach: aktywizacja młodzieży lokalnej, rozpowszechnianie wiedzy o samorządzie terytorialnym oraz działalność konsultacyjna. Ideą przyświecającą istnieniu tego typu organów konsultacyjnych było wspieranie samorządności i zapewnienie młodym członkom wspólnot samorządowych udziału w decyzjach, które ich dotyczą" ${ }^{26}$. Tomasz Moll podkreślając wyraźnie konsultacyjny charakter rad, słusznie osadza ich działalność w kontekście zadania wspierania i upowszechniania idei samorządowej wśród mieszkańców gminy, w tym zwłaszcza wśród młodzieży ${ }^{27}$. Wydaje się, iż ze względu na ograniczony zakres podmiotowy uczestnictwa w radach młodzieżowych na plan pierwszy wysuwa się wspieranie i upowszechnianie idei samorządowej właśnie wśród młodzieży ${ }^{28}$. Mówiąc jeszcze inaczej działalność młodzieżowych rad ma przyczyniać się do budowy społeczeństwa obywatelskiego ${ }^{29}$.

Obok przytoczonych wyżej celów, wskazać można dodatkowo, iż celem funkcjonowania rad jest „nauka obywatelskiego funkcjonowania”, tj. wypracowywania konsensusu w warunkach demokratycznych, sztuki przekonywania do swoich argumentów, współdziałania, ale również godzenia się z przegraną. W tym zakresie można dostrzegać dwie płaszczyzny, na których może nastąpić ta nauka. Po pierwsze są to stosunki wewnętrzne, czemu bez wątpienia będzie sprzyjać zbliżenie struktur (ale nie ich powielenie) do organu stanowiąco-kontrolnego gminy. Po drugie, nauka ta ma miejsce w relacjach zewnętrznych między radą młodzieżową, a przede wszystkim radą gminy. Możliwość konsultacji z młodzieżą (a od niedawna również z osobami starszymi w ramach gminnych rad seniorów) sprzyja włączaniu w proces decyzyjny poprzez „przyciąganie” do centrum decyzyjnego, co w dalszej perspektywie rozwoju młodych ludzi zapobiega wykluczeniu społecznemu ${ }^{30}$. Władza publiczna nie może odebrać młodzieży wolności decyzji co do zaangażowania się lub pozostawania biernym względem samorządu, może jednak dbać o to, aby decyzje te były świadome ich konsekwencji ${ }^{31}$.

Funkcjonowanie młodzieżowych organów konsultacyjnych służy również organom samorządowym. Wynika to ze zmniejszenia niepewności co do decyzji podejmowanych przez organy gmin, dzięki informacjom uzyskiwanym od organów konsultacyjnych. W założeniu pozwala to zapobiegać konfliktom społecznym.

\footnotetext{
25 A. Szewc [w:] Ustawa o..., s. 116.

26 B. Dolnicki, Młodzieżowe rady..., LEX/el.

27 T. Moll [w:] Ustawa o samorządzie gminnym. Komentarz, red. B. Dolnicki, Warszawa 2010, s. 95.

${ }_{28}$ T. Moll, Młodzieżowe rady..., s. 39.

29 Z. Niewiadomski [w:] Ustawa o..., s. 70.

so W zakresie wykluczenia zob. np.: R. Giermakowska, Wykluczenie społeczne. Cechy konstytutywne kategorii i ich empiryczne egzemplifikacje [w:] Polityka społeczna w życiu społeczno-gospodarczym kraju, red. A. Rączaszek, W. Koczur, Katowice 2007.

31 Słowa te są trawestacją cytatu Ireny Lipowicz poświęconego prywatności w Internecie zob.: I. Lipowicz, O mądre państwo i wrażliwe prawo, Warszawa 2013, s. 53.
} 


\section{Zagadnienia ustrojowe młodzieżowych organów konsultacyjnych}

Utworzenie młodzieżowej rady gminy powinno zostać zainicjowane przez „zainteresowane środowiska”. Ustawodawca nie precyzuje tego pojęcia ani co do ilości osób uprawnionych do wystąpienia z wnioskiem do rady gminy, ani ich składu osobowego. Używa także formy mnogiej stanowiąc jednocześnie, iż środowiska te występują $\mathrm{z}$ wnioskiem a nie wnioskami o powołanie rady gminy. Zastosowane sformułowanie należy osadzić w pewnej konwencji językowej nieprzesądzającej jednak o ilości podmiotów uprawnionych do wystąpienia $\mathrm{z}$ wnioskiem do rady gminy. Podobnie należy ocenić wymóg wniosku - złożenie więcej niż jednego postulatu powołania młodzieżowej rady gminy nie przekreśla legalności takiego działania.

Ustawodawca nie sprecyzował także kręgu osób uprawnionych do wystąpienia z wnioskiem o utworzenie młodzieżowej rady gminy ani nie zróżnicował mocy wniosku na wyrażenie zgody w zależności od wybranego środowiska. Najbardziej odpowiednie wydaje się wystąpienie $z$ wnioskiem przez samą młodzież lub ich rodziców lub nauczycieli z terenu gminy. Ważne jednak, aby wystąpienie $z$ takim wnioskiem przez rodziców lub nauczycieli odbyło się po przedyskutowaniu tego zagadnienia z młodzieżą, w przeciwnym razie funkcjonowanie tego organu może nie znaleźć akceptacji wśród młodzieży lub być fikcyjne ${ }^{32}$. Za zainteresowane środowiska uznać należy także „placówki i instytucje oświatowe, rady szkół, rady pedagogiczne"33. W obecnym stanie prawnym nie jest jednak możliwe aby inicjatywa o utworzeniu rady młodzieżowej była podjęta przez samych radnych ${ }^{34}$. Za taką wykładnią przemawia treść art. 5c ust. 2 u.s.g., dotyczącego gminnej rady seniorów, w którym wyraźnie oddzielono „własną inicjatywę rady” od „wniosku zainteresowanych środowisk" do tworzenia gminnej rady seniorów. Tym bardziej trudno uznać za „zainteresowane środowiska” wójta, burmistrza czy prezydenta miasta.

Należy podkreślić wyrażony w literaturze pogląd, iż w sytuacji braku prawnie określonych wymogów wniosku o powołanie młodzieżowej rady gminy (treść, forma) nadmierne biurokratyzowanie procedury wnioskowej byłoby niekorzystne, wystarczy bowiem zwyczajne sformułowanie postulatu do rady gminy o powołanie rady młodzieżowej ${ }^{35}$.

32 Taki sam postulat zgłoszono w Standardach funkcjonowania w Polsce młodzieżowych rad gmin, młodzieżowych rad powiatu. Tak samo M. Fijałkowski, Młodzieżowa rada gminy jako organ o charakterze konsultacyjnym [w:] Zastosowanie idei public governance w prawie administracyjnym, red. I. Niżnik-Dobosz, Warszawa 2014, s. 379.

33 A. Szewc [w:] Ustawa o..., s. 117.

34 Inaczej jednak T. Moll, Ustawa o ..., s. 93.

35 A. Szewc [w:] Ustawa o..., s. 116-117; T. Moll [w:] Ustawa o..., s. 93 
Brak odnośnej regulacji dotyczącej młodzieżowych rad powiatów oraz sejmików (rad) wojewódzkich pozwala wyłącznie w ograniczonym zakresie odnieść się do ewentualnie projektowanej i poświęconej im regulacji. Przyjęcie przez ustawodawcę możliwości tworzenia młodzieżowych rad powiatów powinno odbywać się z poszanowaniem podmiotowości wspólnoty powiatowej. Nie wydaje się celowe, aby z takim wnioskiem mogła wystąpić rada gminy bądź też młodzieżowa rada gminy, lecz wyłącznie zainteresowane środowiska powiatu. Wynika to również z niezależności między poszczególnymi jednostkami samorządu terytorialnego różnych stopni. Ze względu na wielkość województwa i wyłącznie prawny aspekt wspólnotowości regionalnej, tworzenie młodzieżowych rad (sejmików) wojewódzkich winno odbywać się wyłącznie $\mathrm{z}$ inicjatywy sejmiku województwa.

Zgoda na utworzenie młodzieżowej rady gminy jest wyłączną kompetencją rady gminy. Zgoda taka zapada zwykłą większością głosów ${ }^{36}$. Udzielenie takiej zgody skutkuje koniecznością przyjęcia statutu młodzieżowej rady gminy, w którym muszą się znaleźć tryb wyboru członków rady i zasady jej działania. Podczas prac nad ustawą ${ }^{37}$ wprowadzającą młodzieżową radę gminy do polskiego porządku prawnego wskazywano, iż decydowanie o statucie przez radę gminy w zasadzie czyni pozbawionym sensu eksperyment dydaktyczny jakim jest młodzieżowa rada gminy ${ }^{38}$.

W zgodnej opinii organów nadzoru i sądownictwa administracyjnego „powołanie młodzieżowej rady miasta oraz nadanie jej statutu stanowi akt prawa miejscowego w rozumieniu art. 40 ust. 1 ustawy o samorządzie gminnym" ${ }^{39}$. Oznacza to między innymi, iż jego obowiązywanie uzależnione jest od publikacji w wojewódzkim dzienniku urzędowym, musi spełniać również warunki odpowiednio długiego vacatio legis. W ocenie organu nadzoru: „Wydany akt adresowany jest do obywateli i dotyczy ich praw oraz obowiązków. Uchwała ma charakter aktu ogólnego, kierowanego do nieokreślonego kręgu adresatów i wywołującego skutki prawne poza strukturami organizacyjnymi gmin. Akt ten posiada cechy ogólności i abstrakcyjności, które pozwalają uznać dany akt za normatywny i powszechnie obowiązujący. Warto zauważyć, iż jest on wydany na podstawie i w granicach

36 Z. Niewiadomski [w:] Ustawa o..., s. 71.

37 Druk sejmowy nr 2711/III kad.

38 Biuletyn Komisji Sejmowych nr 4003/III kad. oraz Stenogram sprawozdania Komisji Samorządu Terytorialnego i Polityki Regionalnej o stanowisku Senatu w sprawie ustawy o zmianie ustaw: o samorządzie gminnym, o samorządzie powiatowym, o samorządzie województwa, o administracji rządowej w województwie oraz o zmianie niektórych innych ustaw (druki nr 2711 i 2737) z 10.4.2001 r.

${ }^{39}$ Rozstrzygnięcia nadzorcze Wojewody Dolnośląskiego z 19.1.2010 r. (NK.II.PK1.0911-1/10), Lex/el., nr 569946) i 14.6.2010 r. (NK.II.MS6.0911-10/10-1), Lex/el., nr 1731947. Wyrok WSA w Gliwicach z 2.6.2015 r., sygn. akt IV SA/Gl 979/14, gdzie sąd wpadkowo podniósł, iż uchwała taka jest aktem prawa miejscowego. 
upoważnienia zawartego w ustawie, co stanowi konstytucyjny warunek uznania uchwały organu gminy za akt prawa miejscowego" ${ }^{40}$.

Regulacja ustawowa nie precyzuje kto ma wchodzić w skład młodzieżowej rady gminy. Jednak ze względu na ratio legis regulacji naturalne wydaje się, iż w pracach tej rady (skład) powinna brać udział młodzież. Pojęcie młodzieży nie jest sprecyzowane prawnie, wpisuje się jednak w pewien schemat dorastania (dzieci, młodzież, dorośli). Wydaje się, iż tylko pewną pomocą może być cywilistyczna konstrukcja uzyskiwania pełnej zdolności do czynności prawnych, jest ona jednak zawodna w przypadku osób powyżej 18 roku życia a przed ukończeniem szkoły ponadgimnazjalnej, które zwykle zaliczane są do młodzieży. W konsekwencji wskazanych trudności warte rozważenia jest stanowisko, iż młodzieżą są osoby w wieku od rozpoczęcia nauki w gimnazjum do ukończenia szkoły ponadgimnazjalnej ${ }^{41}$. W przypadku jednak braku precyzji ustawodawcy można przyjąć również inne granice tego pojęcia i zaliczać do młodzieży osoby studiujące do 24 roku życia, chociaż ratio legis regulacji wydaje się przemawiać przeciwko takiemu rozwiązaniu. Należy bowiem dostrzec, iż młodzieżowa rada gminy „wprzęga” w proces decyzyjny co do zasady osoby nieposiadające biernego (i czynnego) prawa wyborczego. Osoba kończąca 18 rok życia uzyskuje prawo do bycia wybranym w wyborach do organów przedstawicielskich gminy, powiatu, województwa samorządowego (art. $11 \S 1$ pkt 5 w zw. $z$ art.10 $\$ 1$ pkt 3 Kodeksu wyborczego ${ }^{42}$ ) i tam może realizować swoje prawa polityczne ${ }^{43}$. Dodatkowo znaczące rozszerzenie znaczenia pojęcia młodzieży czyni prawdopodobną sytuację jednoczesnego zasiadania przez tę samą osobę w radzie młodzieżowej i radzie gminy, co z punktu widzenia celu istnienia obu rad nie wydaje się właściwe. Niektóre $z$ gmin w statutach określają jednak takie zakazy ${ }^{44}$. W skład rady nie muszą na pewno jednak wchodzić wyłącznie osoby pełnoletnie, tym bardziej, iż konsultacyjny charakter tego ciała nakazuje uwzględnić przedział różnych grup wiekowych młodzieży w gminie ${ }^{45}$. Faktycznie

40 Rozstrzygnięcie nadzorcze Wojewody Dolnośląskiego z 19.1.2010 r. (NK.II.PK1.0911-1/10), Lex/el., nr 569946.

41 Wydaje się, iż większość statutów tak właśnie postrzega młodzież, chociaż zdarzają się również takie, które przewidują wybór uczniów szkół podstawowych, zob.: M. Fijałkowski, Młodzieżowa rada..., s. 379.

42 Ustawa z 5.1.2011 r. - Kodeks wyborczy, Dz.U. Nr 21, poz. 112 ze zm.

43 Tak samo T. Moll, Młodzieżowe rady gminy, „Wspólnota” 2005, nr 15, s. 38; M. Augustyniak, Młodzieżowa rada gminy [w:] Prawa i obowiązki radnego jednostki samorządu terytorialnego, Lex/el. 2014.

44 Uchwała nr XXV/190/05 Rady Gminy Kwilcz z 28.4.2005 r. w sprawie powoływania Młodzieżowej Rady Gminy w Kwilczu i nadania jej Statutu, Dz.Urz. Woj. Wielkopolskiego Nr 80, poz. 2308 ze zm.

45 Z. Niewiadomski [w:] Ustawa o..., s. 72. Należy podzielić pogląd o pożądanym apolitycznym charakterze rady młodzieżowej - zob.: M. Mączyński, Ustawa o..., s. 141. Pogląd taki wyrażono również w Standardach funkcjonowania w Polsce młodzieżowych rad gmin, młodzieżowych rad powiatu. 
w niektórych gminach ich władze powierzają młodzieżowym radom gminy również reprezentację interesów dzieci ze szkół podstawowych ${ }^{46}$, a w niektórych wyłączają prawną możliwość zasiadania w radzie uczniom szkół ponadgimnazjalnych ${ }^{47}$, do czego należy odnieść się krytycznie. Zdarzają się również dodatkowe warunki biernego prawa wyborczego w postaci oceny dobrej z zachowania ${ }^{48}$.

W sensie celowościowym należy opowiedzieć się przeciwko uczestnictwu z prawem głosowania w obradach młodzieżowych rad, osób niezaliczanych do młodzieży, np. rodziców lub nauczycieli etc. Przemawia za tym fakt, iż młodzieżowe rady gmin mają być reprezentacją głosu młodzieży gminnej, nie zaś osób dorosłych. Z perspektywy przepisów prawa problematyczna mogłaby okazać się jednak w praktyce próba uchylenia w trybie nadzoru regulacji przewidującej wchodzenie w skład rady młodzieżowej osób dorosłych, zwłaszcza iż w przypadku tego ostatniego pojęcia pojawiają się również problemy interpretacyjne jak w przypadku młodzieży.

Kwestią, którą należałoby rozwiązać również ustawowo jest powoływanie w skład rady, młodzieży spoza gminy lecz uczęszczającej do szkół na terenie gminy, w której powołano radę młodzieżową. Należy zgodzić się z E. Gierach, że cel istnienia młodzieżowej rady gminy „usprawiedliwia wprowadzenie ograniczenia czynnego i biernego prawa wyborczego do grona osób stale zamieszkujących na terytorium gminy ${ }^{49}$. Dodatkowo ograniczenia takie mogą wynikać z podmiotowych uprawnień politycznych przysługujących członkom danej wspólnoty samorządowej. Niektóre gminy wprowadziły obostrzenia dotyczące uczniów niezamieszkujących na terenie gminy ${ }^{50}$.

Liczba osób wchodzących w skład rady młodzieżowej ${ }^{51}$, sposób przeprowadzenia wyborów, kadencyjność, treść ewentualnego ślubowania, ustanie członkostwa, głosowanie, model współpracy z radą gminy i wójtem, organy wewnętrzne rady, możliwość korzystania z pomieszczeń urzędu gminy itp., to zagadnienia, które są na ogół precyzowane w statucie. Wśród praktyki spotyka się bardzo zróżnicowane rozwiązania w każdej z tych kwestii, przykładowo w zakresie wyborów

46 Zob. uchwała Rady Miejskiej Strzelina z 28.3.2006 r. w sprawie powołania Rady Gminy Strzelin i nadania jej statutu, Dz.Urz. Woj. Dolnośląskiego Nr 88, poz. 1502.

47 Uchwała nr II/7/2014 Rady Gminy Słupsk z 18.12.2014 r. w sprawie powołania Młodzieżowej Rady Gminy Słupsk i nadania jej statutu, Dz.Urz. Woj. Pomorskiego z 2015 r., poz. 24. W uchwale przewidziano możliwość faktycznego zasiadania w radzie uczniom szkół ponadgimnazjalnych do końca kadencji w przypadku wybrania ich jeszcze w czasie gdy byli uczniami szkół gimnazjalnych.

48 Uchwała nr XVI/65/2003 Rady Miejskiej w Wyszkowie z 16.10.2003 r. w sprawie powołania Młodzieżowej Rady Gminy Wyszków i nadania jej statutu, Dz.Urz. Woj. Mazowieckiego Nr 278, poz. 7351 ze zm.

49 E. Gierach, Status prawny..., s. 236.

so Uchwała nr V/39/2015 Rady Gminy Żelazków z 30.3.2015 r. w sprawie powołania Młodzieżowej Rady Gminy Żelazków oraz nadania jej Statutu, Dz.Urz. Woj. Wielkopolskiego z 2015 r., poz. 2686.

51 Spotyka się zróżnicowane rozwiązania, średnio jednak liczba radnych waha się wokół 15. 
od przeprowadzania tajnego głosowania w szkołach aż do wyznaczania osób wchodzących w skład rady przez różne środowiska ${ }^{52}$.

W literaturze spotkać można wielorakie poglądy na strukturę młodzieżowej rady gminy. Marek Mączyński stwierdza wyraźnie, iż młodzieżowa rada gminy „powinna odzwierciedlać strukturę rady gminy wynikającą z ustawy o samorządzie gminnym" ${ }^{53}$. T. Moll wskazuje nawet na możliwe do powołania organy tej rady: prezydium lub zarząd, przewodniczącego rady, wiceprzewodniczącego rady, sekretarza, skarbnika, komisje rady, zespoły problemowe. Również funkcjonowanie rady przypomina radę gminy: obraduje ona na sesjach zwyczajnych i nadzwyczajnych, podejmuje uchwały zwykłą większością głosów, w obecności co najmniej połowy składu rady. Statut przesądza również o inicjatywie uchwałodawczej rady ${ }^{54}$.

Można również dostrzec odmienny pogląd, iż rady młodzieżowe zasadniczo nie powinny być odpowiednikiem rady gminy ${ }^{55}$. Poszukując argumentów za tym stanowiskiem można stwierdzić, iż rada młodzieżowa ma do spełnienia inne zadania niż rada gminy. Również inny i ilościowo o wiele mniejszy jest zakres spraw, którymi może zajmować się rada młodzieżowa. Po drugie w zamyśle ustawodawcy nie było tworzenie „rady gminy bis” z reprezentacją młodzieży. Inne funkcje i zadania stawiane przed radą młodzieżową nakazują ostrożnie podchodzić do czynienia z niej drugiej rady gminy. Gdyby tak jednak miało być wypadało by również pogodzić się z możliwością upolitycznienia rady młodzieży. Po trzecie paradoksalnie właśnie takie podejście spowodowałoby, że młodzieżowa rada gminy stałaby się krytykowaną w doktrynie „zabawą w samorząd” a ograniczonemu zakresowi kompetencji towarzyszyłoby tworzenie rozbudowanych struktur. Prezentowane argumenty odnoszą się również do młodzieżowych rad powiatu i województwa.

W kontekście powyższych uwag należy stwierdzić, iż ustawodawca w bardzo ograniczony sposób reguluje kwestie ustrojowe młodzieżowej rady gminy, pozostawiając organowi stanowiącemu dużą swobodę co do określenia składu, trybu wyboru członków i zasad działania. Nie ulega jednak wątpliwości, iż istnieją trudności w wyznaczeniu ustawowych granic swobody statutowej w zakresie tworzenia młodzieżowych rad gmin.

Założenie racjonalności ustawodawcy wymaga przyjęcia, iż określił on celowo w sposób zamknięty materię statutową przyjmując, iż statut musi wyłącznie regulować tryb wyboru członków i zasady działania rady. Upoważnienie to ma

52 Uchwała nr VI/45/2015 Rady Gminy Raciechowice z 30.4.2015 r. w sprawie powołania Młodzieżowej Rady Gminy Raciechowice oraz nadania jej statutu, Dz.Urz. Woj. Małopolskiego z 2015 r., poz. 3163.

53 Zob. M. Mączyński [w:] Ustawa o..., s. 141.

54 T. Moll, Młodzieżowe rady..., s. 39.

55 T. Augustyniak-Górna, Zasady finansowania..., s. 240 i 242. Podobny postulat zgłoszono w Standardach funkcjonowania w Polsce młodzieżowych rad gmin, młodzieżowych rad powiatu. 
zatem charakter szczegółowy a nie generalny jak w art. 3 ust. 1 u.s.g. ${ }^{56}$ Trudno jednak zrozumieć, dlaczego statut musi ograniczać się wyłącznie do tych dwóch zagadnień i nie może regulować innych kwestii, jak na przykład składu, zasad finansowania, nadzoru itp., chyba, że zagadnienia te będą składać się na pojęcie „tryb wyboru członków i zasady działania”.

Radę gminy ogranicza również bezwzględnie wyrażony ustawowo konsultacyjny charakter rady. Nadawanie jej innego charakteru jest wykraczaniem poza dopuszczalny zakres normowania statutowego. Należy uznać, że w tak zarysowanych granicach, samorząd ma swobodę co do określenia trybu wyboru członków i zasad działania rady młodzieżowej. Uregulowania te nie muszą wiernie imitować rozwiązań ustawy o samorządzie gminnym, zresztą takie rozumowanie czyniłoby bezzasadnym powierzanie regulowania tej materii w drodze statutowej.

\section{Funkcjonowanie młodzieżowych organów konsultacyjnych}

Szczegółowe warunki funkcjonowania młodzieżowych organów konsultacyjnych powinny zostać określone w statucie lub jak twierdzi E. Gierach w regulaminie ${ }^{57}$. O ile zatem kwestie ustrojowe przekazane byłyby do regulacji w statucie, o tyle sprawy bieżącego funkcjonowania określałby regulamin. Wydaje się, iż regulamin ten powinien być przyjęty i ewentualnie zmieniany przez radę gminy, jako organ ustawowo powołany do utworzenia i powołania młodzieżowej rady, a więc władny do określenia ustroju i zasad jej funkcjonowania. Należy jednak przyznać możliwość konsultowania treści regulaminu lub zmian w statucie $\mathrm{z}$ młodzieżową radą gminy.

Jak już zostało wspomniane, możliwe do zastosowania rozwiązania co do funkcjonowania młodzieżowych organów konsultacyjnych zawiera opracowanie Ogólnopolskiej Federacji Młodzieżowych Samorządów Lokalnych. Federacja jednoznacznie przyjmuje szeroki zakres działalności rad młodzieżowych wykraczający poza konsultacyjny charakter. Zgodnie z tym dokumentem każda rada na początku swojej kadencji powinna przeprowadzić diagnozę środowiska lokalnego i dopiero na tej podstawie określić swoje priorytety oraz sformułować szczegółowy program działania. W celu sprawnego przebiegu prac rady, autorzy opracowania proponują powołanie specjalnego opiekuna merytorycznego młodzieży. Wyróżniają także trzy fazy rozwoju każdej rady: rozwoju, stabilizacji i podsumowania. Zdaniem autorów

56 Różne stanowiska w zakresie materii statutowej gminy przytacza np.: A.M. Wierzbica [w:] Ustawa o samorządzie gminnym. Komentarz, red. B. Dolnicki, Lex/el 2010.

57 E. Gierach, Status prawny..., s. 235; E. Gierach, Rola samorzqdu terytorialnego w tworzeniu warunków uczestnictwa młodych ludzi w życiu społeczności lokalnej, „Zeszyty Prawnicze Biura Analiz Sejmowych" 2009, nr 2, s. 118-119. 
wyodrębnienie tych faz obrazuje naturalny spadek zaangażowania w pracach rady i pozwala na zapobieganie negatywnym konsekwencjom przez dostrzeżenie problemu i podjęcie przeciwdziałań przez rady gminy (powiatu). Kontrowersyjnym wydaje się być stwierdzenie autorów opracowania, iż w okresie wakacyjnym i ferii zimowych radni młodzieżowi nie powinni mieć obowiązku angażowania się w prace rady. Dostrzegając potrzebę odpoczynku i legalność wprowadzenia w statucie ograniczeń wakacyjnych, należy jednak stwierdzić, iż młodzieżowa rada gminy nie jest „zabawą w samorząd”, lecz aktywnym uczestnictwem w zakresie ustawowo określonych ram w funkcjonowaniu wspólnoty lokalnej.

Funkcjonowanie młodzieżowej rady wiąże się z koniecznością zapewnienia warunków lokalowych oraz ponoszeniem kosztów funkcjonowania tego ciała przez gminę. Jak wskazuje Teresa Augustyniak-Górna w przepisach prawa nie uregulowano problematyki finansowania rad młodzieżowych oraz ich kontroli. „Z racji bardzo wąsko określonego przez ustawę o samorządzie gminnym zadania tych rad nie ma uzasadnienia dla wprowadzenia instytucji budżetu rad młodzieżowych" ${ }^{58}$. Dodatkowo jak zwraca uwagę autorka, przyznanie uprawnień do swobodnego dysponowania środkami publicznymi nie jest właściwe biorąc pod uwagę, iż w skład omawianych ciał wchodzą wielokrotnie osoby nieposiadające pełnej zdolności do czynności prawnych, a więc niezdolne do swobodnego dysponowania swoim majątkiem ${ }^{59}$. W praktyce wielokrotnie statuty wskazują dopuszczalne źródła dochodów młodzieżowych rad gminnych.

W literaturze można spotkać pogląd, iż związek między młodzieżową radą gminy a radą gminy wykracza poza akt utworzenia. Relacje te można określić mianem merytorycznej nadrzędności bez władczego prawa wkraczania w określanie kierunków działania z jednoczesną możliwością nadzoru nad młodzieżową radą gminy $^{60}$. Należy jednak stwierdzić, że ex lege ustawodawca nie przewidział, żadnych konkretnych (poza konsultacyjnymi) relacji między radami. Ewentualne określenie rady gminy jako organu nadzoru nad radą młodzieżową wymaga każdorazowego dookreślenia w statucie środków nadzorczych oraz warunków zastosowania. Środki nadzoru można rozszerzyć poza legalność, niemniej nie powinny one swoim natężeniem czynić fasadowym omawianego organu, tj. w zakresie konsultacyjnym winna być zapewniona jego samodzielność.

Młodzieżowa rada gminy powinna funkcjonować przy radzie gminy i korzystać z pomocy organizacyjno-technicznej urzędu gminy. Twierdzenie takie znajduje częściowo potwierdzenie w Jednolitym Rzeczowym Wykazie Akt dla organów gminy i związków międzygminnych oraz urzędów obsługujących te organy i związki, który jest załącznikiem nr 2 do rozporządzenia Prezesa Rady Ministrów z 18.1.2011 r. w sprawie instrukcji kancelaryjnej, jednolitych rzeczowych

T. Augustyniak-Górna, Zasady finansowania..., s. 241-242.

Ibidem.

M. Fijałkowski, Młodzieżowa rada..., s. 382. 
wykazów akt oraz instrukcji w sprawie organizacji i zakresu działania archiwów zakładowych ${ }^{61}$. Wykaz akt przewiduje tworzenie dokumentacji w zakresie wyborów do młodzieżowej rady gminy (0030) oraz prac młodzieżowej rady gminy (0031). Ta ostatnia dokumentacja ma charakter materiałów archiwalnych. W przeciwieństwie do rady gminy nie określono wymogu grupowania m.in. uchwał i ich projektów, wniosków i interpelacji jednakże wydaje się właściwym twierdzenie, iż tego typu dokumentacja stanowi dokumentację z prac młodzieżowej rady gminy.

Analogicznych rozwiązań nie zawarto w wykazie akt dla powiatów i samorządów województw co jest kolejnym argumentem przeciw dopuszczalności tworzenia takich ciał na wyższych stopniach samorządu terytorialnego. Ich ewentualne utworzenie nakłada jednak obowiązek rozbudowy wykazu akt ( $§ 4$ ust. 9 rozporządzenia).

\section{Zakończenie}

Współczesna regulacja prawna dotycząca młodzieżowych organów konsultacyjnych jest między innymi odpowiedzią państwa na pojawiające się samorzutnie od początku lat dziewięćdziesiątych młodzieżowe rady gmin ${ }^{62}$ i powiatów. Regulacja ta swoim zakresem obejmuje wyłącznie gminę, nie tworząc szczególnej podstawy prawnej istnienia młodzieżowych rad powiatów i (sejmików) rad województw; jest jednocześnie bardzo lakoniczna i pozostawia dużą swobodę wyboru odpowiednich rozwiązań ustrojowych samym radom gmin. Prowadzi to do swobodnego określania przez samorząd lokalny struktury i funkcjonowania tych ciał młodzieżowych. Swoboda taka jest potrzebna, nie może jednak wykraczać poza ramy określone przez ustawodawcę, np. podważając efektywność kompetencji konsultacyjnych młodzieżowych rad gmin.

Młodzieżowe organy konsultacyjne można określać mianem przejawu polityki młodzieżowej państwa w samorządzie terytorialnym ${ }^{63}$. W tym kontekście warto rozważyć sformułowanie podstawy prawnej tworzącej wyraźną kompetencję tworzenia rad (sejmików) młodzieżowych na wyższych stopniach samorządu terytorialnego. Wszystkie one powinny bowiem wpisywać się w nauczanie młodzieży obywatelskiego funkcjonowania w państwie.

\section{The youth consultative bodies in local self-government}

The article consists of an analysis of regulations concerning the formation of youth consultative bodies in local self-government. The investigated issue

\footnotetext{
61 Dz.U. Nr 14, poz. 67 ze zm.; dalej jako: rozporządzenie.

62 Zob. E. Gierach, Rola samorządu..., s. 118.

63 Zob. np. Polityka młodzieżowa, „Zeszyty Prawnicze Biura Analiz Sejmowych” 2009, nr 2.
} 
is crucial from the perspective of supporting and spreading of the self-governance ideas among the youth, including the development of civic attitudes among the adolescent citizens.

The youth consultative bodies are briefly regulated by the Polish legal system, and their establishment relies solely on the gmina self-government act (Ustawa o Samorządzie Gminnym). However, such organs are also present in other self-government units: voivodeships and powiats.

The current regulation limits the nature of the youth municipal council (młodzieżowa rada gminy) to the role of a consultative body. The inner structure and procedures regarding the election of members of youth municipal council are in sole control of the municipal council (rada gminy), although this control is limited by the municipal council statute which results from the state regulatory acts. 